\section{Alkohol og tidlig død i Russland}

Alkohol har forårsaket over halvparten av dødsfallene hos personer i alderen 15-54 år i Russland de siste årene og er en hovedårsak til de store svingninger i mortalitet blant voksne siden 1980. Den store forskjellen i prematur mortalitet blant voksne i Russland og Vest-Europa kan i hovedsak tilskrives alkohol og tobakk. Det er konklusjonene av en epidemiologisk studie av mortalitet i tre russiske byer, publisert i The Lancet (1).

Forskerne undersøkte dødsårsaker, livsstilsfaktorer og alkoholbruk hos 48557 voksne i alderen 15-74 år basert på opplysninger fra avdødes familie. Forfatterne definerte på forhånd hvilke årsaker til død som i særlig grad kunne være knyttet til alkohol eller tobakk. Slike dødsårsaker ble registrert i 43802 tilfeller. Alkohol var assossiert med $52 \%$ av alle dødsfall i alderen 15-54 år (59\% blant menn og $33 \%$ blant kvinner), og $18 \%$ av alle dødsfall $i$ alderen $55-74$ år.

«Russland må enten stoppe eller skattlegge ulovlig produksjon av sprit, som er antatt å stå for minst $50 \%$ av alkoholinntak i landet. Dette betyr en konfrontasjon med organiserte kriminelle og korrupte offentlig ansatte,» konkluderer en lederartikkel i samme nummer av The Lancet (2).

\section{Oda Riska}

oriska@hotmail.com

Tidsskriftet

\section{Litteratur}

1. Zaridze D, Brennan P. Boreham J et al. Alcohol and cause-specific mortality in Russia: a retrospective case-control study of 48557 adult deaths. Lancet 2009; 373: 2201-14.

2. Alcohol and harm reduction in Russia. Lancet 2009; 373: 2171

\title{
Knuste liv
}

\author{
«Jeg var på tur hjem fra markedet sammen med en gruppe kvinner \\ og menn da vi ble angrepet av væpnede menn. De tok alle kvinnene med \\ til leiren og holdt oss fanget i flere dager. Jeg ble voldtatt både på dagen \\ og om natten. Ofte var de fem samtidig.» \\ Kvinne, Darfur, Sudan
}

Historien er dessverre ikke uvanlig. Hvert år blir millioner av mennesker utsatt for seksualisert vold (1). Seksualisert vold inkluderer voldtekt, overgrep, utnyttelse, tvungen sterilisering, mutilering av kjønnsorganer og seksuelle handlinger i bytte mot tjenester som beskyttelse, mat eller penger (2). Leger Uten Grenser har nylig utgitt rapporten «Shattered lives» som handler om medisinsk behandling og støttetiltak til ofrene (3).

\section{En militær strategi}

I konflikter vil ødelagte samfunnsstrukturer, mange kvinnelige familieoverhoder og migrasjon gjøre befolkningen utsatt. Seksualisert vold er i økende grad brukt som militær strategi for å ydmyke og ødelegge samfunn. De siste årene har vi sett dette satt i system i stor skala for å oppnå politiske resultater. Seksualiserte voldsstrategier kan tjene flere forhold, som soldaters belønning og motivasjon, tortur, demoralisering av den stridsdyktige mannlige befolkningen, til å tvinge befolkninger vekk fra sine hjemtrakter eller for å spre hiv blant den fiendtlige befolkningen. Vi har blant annet sett det i Bosnia, Rwanda, Liberia, Sierra Leone, Kongo og Sudan, og det pågår mange steder fortsatt, også der konflikten for lengst er over.

\section{Mange tier}

De fysiske, psykiske, sosiale og økonomiske konsekvensene av denne voldsutøvelsen er enorme, ikke bare for alle kvinnene og mennene, guttene og jentene som er voldtatt, utnyttet og misbrukt. Hele familien lider. Stigmatisering, skam, redsel for å bli utstøtt, mangel på medisinsk kompetanse og tilbud, koblet med begrensede juridiske rettigheter og muligheter gjør at mange, og kanskje de fleste, velger å tie og avstår fra å oppsøke behandling.

\section{Leger Uten Grensers arbeid med seksualisert vold}

Ofrene for seksualisert vold er i en medisinsk akuttilstand. Hver måned kommer over 1000 til Leger Uten Grensers kli- nikker. I 2007 registrerte vi 12791 pasienter utsatt for slik vold i 127 prosjekter. Vi ser at dersom forholdene legges til rette med bred opplysning om hjelpetilbudet, mulighet til private konsultasjoner, trenet personell, adekvat håndtering av hiv, hepatitt $\mathrm{B}$ og tetanusprofylakse, tilbud om nødprevensjon, behandling av seksuelt overførbare sykdommer, fysiske skader og ikke minst psykososial støtte og oppfølging, søker mange behandling - mange også innen 72 timer som er grensen for når vi gir hivprofylakse. Vi utsteder og lagrer alltid, opptil 20 år enkelte steder, et medisinsk sertifikat til eventuell fremtidig bruk i rettssystemet. I stadig flere land blir disse nå akseptert og lagt til grunn for domsavsigelser.

Seksualisert vold er et omfattende problem som må bekjempes på mange arenaer. Leger Uten Grenser forsøker å innlede samarbeid med andre organisasjoner, ofte lokale, for å sikre en mer helhetlig tilnærming. Opplysningskampanjer, rettshjelp

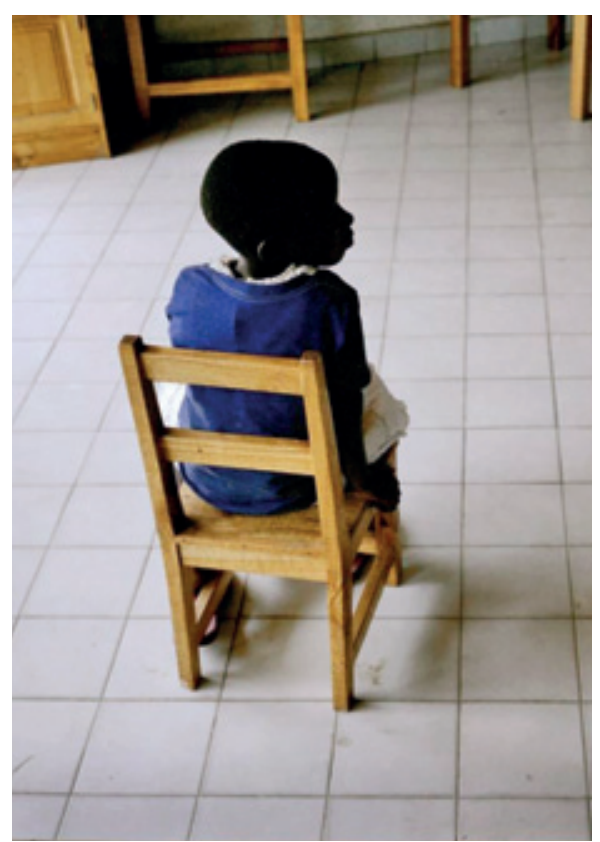

Jente voldtatt av far. Foto Benedicte Kurzen/VII Mentor (3). Gjengitt med tillatelse 